\title{
G.A. COHENS POLITISKE FILOSOFI
}

\section{Nicholas Vrousalis}

The political philosophy of G.A. Cohen: back to socialist basics.

Bloomsbury Academic, 2015

164 sider, $83,99 \$ / 575 \mathrm{kr}$

Inden for den politiske filosofi har spørgsmålet om fordelingsmæssig retfærdighed nydt betydelige interesse i de senere år. Ofte fremhæves liberale bidrag som de, der er leveret af John Rawls og Ronald Dworkin, eller libertære positioner som den Robert Nozick stod for. I ethvert værk der forholder sig til disse tre hovednavne i litteraturen vil ét navn gå igen som en central fortolker og kritikker af dem alle: G.A. Cohen. Nicholas Vrousalis' bog The Political Philosophy of G.A. Cohen - Back to Socialists Basics er det første forsøg på at give en samlet fremstilling af Cohens politiske filosofi. Den canadisk-fødte filosof fremstod frem til sin død i 2009 som en væsentlig bidragsyder til den politiske filosofi. Alligevel ville mange tøve med at sætte ham op ved siden af de allerstørste. Det kan skyldes bidragenes lidt særegne natur. De fleste bidrag fremkom netop som en kritik af andre. Måske derfor betragtes og diskuteres hans forfatterskab ofte som en lang række mere eller mindre isolerede bidrag, der har værdi fordi de fremhæver styrker og svagheder ved andre, men ikke nødvendigvis udtrykker et egentligt positivt bidrag. Bidragene fra manden der spillede en hovedrolle i udformningen af den analytiske marxisme, og samtidig blev en af de helt store i debatten om fordelingsmæssig retfærdighed, præsenteres nu i ét samlet værk. Cohens første bog, Karl Marx's Theory of History - A Defense, var et af de mest berømte moderne værker om historisk materialisme, og hans sidste, Why Not Socialism? var et moralsk forsvar for socialistiske idealer om lighed og fællesskab. Så ingen kan være i tvivl om den enorme bredde i produktionen. Men er der også en rød tråd? I 1989 udgav Cohen en bog med undertitlen Themes from Marx - På sin vis kunne Vrousalis have kaldt sin bog Themes from Cohen. I hvert fald søger den at adressere og fremhæve en række temaer der går igen igennem store dele af Cohens forfatterskab. Det drejer sig om følgende emner (i nævnte rækkefølge): Historisk Materialisme, Frihed, Lighed, Udbytning, Fællesskab og Markedet.

I kapitlet om historisk materialisme beskrives Cohens forsøg på at forsvare den marxistiske teori om historiens udvikling. Det bliver til en interessant diskussion 
om både Cohens specifikation af centrale begreber, såsom produktivkræfterne; Cohens tese om at deres udvikling har forrang i forklaringen af historiens gang; og de funktionsforklaringer Cohen anvender til at beskrive forholdet mellem basis og overbygning, hvor ændringer i sidstnævnte sker på baggrund af at disse ændringer er gavnlige for førstnævnte. Herefter noterer Vrousalis, som også Cohen selv har gjort det, et skifte i Cohens politiske filosofi. Efter udgivelsen af bogen om historisk materialisme, blev det i høj grad normative spørgsmål der optog Cohen. De første favntag med dette skete som en reaktion på Nozick højre-libertære kritik af omfordeling. I kapitlet om frihed beskrives det, hvorledes Cohen argumenterede for at en fordeling af ejendom også er en fordeling af frihed; samt hans kritik af Nozicks principper for, hvornår overførsel og tilegnelse af ejendom er retfærdigt. Kapitlet kommer vidt omkring og inddrager også mindre diskuterede tekster, som eksempelvis den gode 'Freedom and Money' Styrken her er klart en hjælpsom fremstilling af Cohens kritik af Nozick. I kapitlet om lighed går det overordentligt stærkt. Cohens kritik af Dworkins ideal om ressourcelighed gennemgås og efterfølges med Cohens kritik af Rawls. I hastigt tempo beskrives Cohens såkaldte held-egalitaritiske lighedsideal, hvor en fordeling er retfærdig når den ikke afspejler vores (u)held i sociale eller naturlige omstændigheder, men i stedet vores valg og præferencer. Imod Rawls fremførte Cohen at Rawls' berømte differensprincip, der tillader uligheder der gavner de dårligst stillede, tillader langt færre uligheder end det almindeligvis antages. Afslutningsvist siger Vrousalis lidt om, hvorledes det er interessant at Cohens held-egalitarisme adskiller sig fra det klassiske marxistiske ideal om at yde efter evne og nyde efter behov.

I kapitlet om udbytning identificerer Vrousalis det han opfatter som en ændring i Cohens position. Vrousalis argumenterer for at Cohen oprindeligt mente at udbytning var uretfærdig fordi det afspejlede en uretfærdig fordeling af produktionsmidlerne/ressourcerne i samfundet. Dette synspunkt skulle så senere være blevet afløst af et synspunkt, hvor udbytning kan foregå på baggrund af retfærdige fordelinger. Vrousalis demonstrerer fint Cohens oprindelige tilslutning til et sådant synspunkt, men argumentet for et skifte er sværere at følge idet det baserer sig på passager der også beskriver et skifte i hvad Cohen ser som en uretfærdig fordeling. I kapitlet om fællesskabet trækker Vrousalis trådene fra Marx' vision om frihedens rige, til det fællesskab Cohen flere steder opstiller som et ideal der skal supplere eller komplementere lighedsidealet. Cohen kritiserer markedet ved flere lejligheder. Derfor 
er det helt oplagt at et separat kapitel er dedikeret til dette. Vrousalis identificerer en kritik af markedet der går på de fordelinger markedet skaber, og en der mere betoner hvorledes markedet ikke afspejler fællesskabet. Denne kritik mente Cohen også relevant at rejse over for de såkaldte markedssocialistiske idealer, der fremkom særligt efter Sovjetblokkens sammenbrud. Endeligt konstateres det, at Cohen må have tilsluttet sig en fællesskabsbaseret planlægning, men at det er sværere at finde egentlige positive argumenter for dette.

Afslutningsvist må man sige at bogen er et vigtigt bidrag. Det er rigtigt set af Vrousalis, at fokusere på at afrapportere Cohens position frem for at forsøge i overdreven grad at inddrage senere udviklinger og kritikker. Det betyder ikke at bogen føles som et hurtigt resume, men snarere at de kommentarer og vurderinger der gives handler mere om hvordan de forskellige elementer i Cohens vidtforgrenede forfatterskab kan siges at passe sammen. Da Steven Lukes ville skrive en bog om marxisme og moral bemærkede Cohen tørt, at det ville blive en kort bog. Der var ikke meget at sige, mente Cohen dengang. Omvendt må det siges at en bog om Cohens omfattende og forskelligartede bidrag til den politiske filosofi ikke i udgangspunktet inviterer til at bogen bliver kort. Men Vrousalis har skrevet en kort bog. Derfor sidder jeg som læser med en blandet følelse da den slutter på side 134. På den ene side, er det en dyd at fatte sig i korthed, på den anden side betyder det også at nogle emner bliver behandlet så kortfattet at man berettiget kan spørge om bogen yder dem retfærdighed. At behandle Cohens bidrag til debatten om fordelingsmæssig retfærdighed, i et enkelte kapitel på 20 sider, der både spænder over kritikken af Rawls og Dworkin, er ambitiøst og i sidste ende ikke tilfredsstillende. Her går Vrousalis så hurtigt frem, at forudsætningerne for at følge med bliver betydeligt større og udeladelserne ligeså. Det ændrer ikke ved det overordnede indtryk. Det er en vellykket udgivelse, der med sin koncise fremstilling og skarpe betragtninger er et vægtigt bidrag til at forstå de forskellige elementer i Cohens forfatterskab. At det ikke kan erstatte læsning af de originale bidrag er en selvfølge.

\section{Andreas Brøgger Albertsen}

